\title{
Immunohistochemical study of Langerhans cells in periapical lesions; correla- tion with inflammatory cell infiltration and epithelial cell proliferation
}

\author{
Celia Carrillo ${ }^{1}$, Miguel Peñarrocha ${ }^{2}$, Maria Peñarrocha ${ }^{3}$, Francisco Vera ${ }^{4}$, David Peñarrocha ${ }^{5}$ \\ ${ }^{1}$ DDS Master of Oral Surgery and Implantology. Valencia University Medical and Dental School \\ ${ }^{2} \mathrm{PhD}$, DDS Professor of Oral Surgery. Director of the Master of Oral Surgery and Implantology. Valencia University Medical \\ and Dental School \\ ${ }^{3} \mathrm{PhD}$, DDS Associate professor of Oral Surgery. Valencia University Medical and Dental School \\ ${ }^{4} \mathrm{PhD}$, DDS Professor of Pathology, Faculty of Medicine and Dentistry, Valencia University; Chairman of Pathology II, "La Fe" \\ University Hospital, Valencia, Spain \\ ${ }^{5}$ Student of Master of Oral Surgery and Implantology. Valencia University Medical and Dental School
}

Correspondence:

Cirugía Bucal. Clínicas Odontológicas

Gascó Oliag 1

46021-Valencia. Spain

Miguel.Penarrocha@uv.es

\author{
Carrillo C, Peñarrocha MA, Peñarrocha M, Vera-Sempere F, Peñarrocha \\ D. Immunohistochemical study of Langerhans cells in periapical lesions: \\ correlation with inflammatory cell infiltration and epithelial cell prolife- \\ ration. Med Oral Patol Oral Cir Bucal. 2010 Mar 1;15 (2):e335-9. \\ http://www.medicinaoral.com/medoralfree01/v15i2/medoralv15i2p335.pdf \\ Article Number: $2618 \quad$ http://www.medicinaoral.com/ \\ (C) Medicina Oral S. L. C.I.F. B 96689336 - pISSN 1698-4447 - eISSN: 1698-6946 \\ eMail: medicina@medicinaoral.com \\ Indexed in: \\ -SCI EXPANDED \\ -JOURNAL CITATION REPORTS \\ -Index Medicus / MEDLINE / PubMed \\ -EMBASE, Excerpta Medica \\ -SCOPUS \\ -Indice Médico Español
}

\begin{abstract}
Aim: The aim of this study is to determine the presence and distribution of Langerhans cells in periapical lesions, and correlate this with inflammatory cell infiltration and epithelial cell proliferation. Material and Methods: Seventy chronic dental periradicular lesions, obtained during periapical surgery from 70 patients, were included in this study, including: 46 granulomas, 18 scar tissue and 6 periradicular cysts. Immunohistochemical staining was performed using the following markers: $\mathrm{CD} 3$ to analyze the inflammatory infiltrate, CD1a to determine the presence of Langerhans cells and Ki67 to analyze the epithelial cell proliferation. The CD1a immunostaining density was established following Cincura (2007) criteria, being classified ranging from intense (3), moderate (2), discrete (1) or no (0) immunostaining. CD3 and Ki67 staining was evaluated following the Liapatas et al. scale, as: 0) no cells stained; 1) weak stain or few cells stained (11-25\%); 2) moderate staining or some cells stained (26-75\%); 3 ) intense staining or many cells stained (more than $76 \%$ ). Results: Langerhans cells were found in $32.8 \%$ of the periapical lesions being more intense in the epithelialized lesions. CD3 immunohistochemical staining was found in all lesions, but with different values in relation to histological subtypes. Ki67 was positive in all epithelialized lesions, although with a moderate staining. Conclusions: Langerhans cells appeared to be associated with T-lymphocyte infiltration and the proliferative potential of the epithelial tissue in periapical lesions.
\end{abstract}

Key words: Periapical lesion, immunochemistry, Ki67, CDla, inflammatory cell, Langerhans cell, epithelial proliferation. 


\section{Introduction}

Langerhans cells (LCs) are dendritic antigen-presenting cells that initiate a primary T-lymphocyte-dependent immune response (1). These cells originate from the bone marrow (2), and are present in the oral epithelium (1). Available evidence indicates that LCs play an important part in cell-mediated immune reactions as well as in the pathogenesis of periapical lesions (3).

LCs were observed in areas of intense inflammation, evidenced by large numbers of lymphocytes, polymorphonuclear leucocytes and plasma cells. The finding of lymphocytes adjacent to LCs, suggested increased antigen challenge and antigen-processing activity and that T-lymphocytes may act as effectors cells in the pathogenesis of the cyst, after receiving information from stimulated LCs (4).

The tissues of granulomas and radicular cysts are infiltrated by specific and nonspecific cells involved in the local immunological responses (5). Kontiainen et al. (6), observed that over $50 \%$ of the total cells studied in periapical lesions were lymphocytes and more than half the lymphocytes infiltrating the lesions were $\mathrm{T}$ cells.

The monoclonal antibody Ki-67 detects a nuclear antigen that is present only in proliferating cells (7). Suzuki et al. (3) found a significant correlation between the proliferative potential of the epithelium in periapical lesions and intraepithelial CD1a-labeled cell density. Inflammatory infiltrate in periapical lesions has been studied by many authors $(3,6,8-10)$, we believed it would be interesting to study the characteristics of infiltrating inflammatory cells and the proliferative potential of the epithelium, and to discuss the possible relation with CDla-labeled cells, to improve the knowledge of the immunological mechanism in the etiopathogeny of periapical lesions. The hypothesis that Langerhans cells are associated with $\mathrm{T}$ lymphocyte infiltration and proliferative potential of the epithelial tissue in periapical lesions is considered. The aim of this study is to determine the presence of Langerhans cells in periapical lesions, and correlate with inflammatory cell infiltration and epithelial cell proliferation.

\section{Materials and Methods}

Periapical surgery was carried out on 82 patients between January 2003 and January 2005. The indications for periapical surgery, based on the protocol of the Spanish Society of Oral Surgery were (11): 1) periapical disease affecting permanent teeth subjected to endodontic treatment, with the presence of pain or swelling, and repeated failure of root canal treatment; 2) periapical disease with pain or swelling and involving permanent teeth subjected to endodontic treatment with bridge abutments or teeth with posts presenting extraction difficulties; 3) symptomatic gutta-percha overfilling or foreign bodies presenting orthograde extrac- tion difficulties; 4) radiotransparencies over 8 to $10 \mathrm{~mm}$ in diameter; and 5) endodontic treatment and periapical surgery in a single session. No periapical surgery was carried out in the acute phase or with chronic periapical abscess exacerbation. Patients with sufficient sample for histological and immunohistochemical analysis and with non-contributory medical histories were included. Twelve patients were excluded for absence of periapical lesion, analyzing 70 histological samples from 70 patients ( 43 women and 27 men); mean age was 34.9 years (range 16-54 years).

\section{- Histology and immunohistochemistry}

All biopsies were taken at the time of periapical surgery, and immediately fixed in $10 \%$ formaldehyde solution, with a surgical specimen/fixator volume ratio of $1 / 10$. The samples were embedded in paraffin using an automated tissue processor. Microtome serial sections (6 to 8 microns) were later made with a Minot rotation microtome. Every fourth slide was deparaffinized and systematically stained with hematoxylin-eosin. Serial sections of original histological slices were treated (silinizated) for immunohistochemical staining. The immunohistochemistry (IHC) was done using an automated immunostainer. The IHC methods used were the peroxidase-antiperoxidase technique for polyclonal antibodies, and the avidin-biotin complex technique for monoclonal antibodies. In this study, marker CD1a was used to determine the presence of Langerhans cells, $\mathrm{CD} 3$ was used to determine the presence of T lymphocytes, and Ki67 to analyze the epithelial cell proliferation. The markers, clone, source and dilution used, are shown in Table 1.

Table 1. Markers used in immunohistochemical study.

\begin{tabular}{|c|c|c|c|}
\hline Test & Clone & Source & Dilution \\
\hline CD1a & MTB-1 & Novocastra Laboratories & Prediluted \\
\hline CD3 & UCHT1 & Dakocytomation & $1 / 50$ \\
\hline Ki67 & MIB-1 & Dakocytomation & $1 / 75$ \\
\hline
\end{tabular}

The histological sections were examined under a $\mathrm{Bx} 45\left[{ }^{\circledR}\right.$ microscope by two observers (FVS, CCG), assigning the result by consensus. The specimens were classified as radicular cyst, scar tissue or granuloma (10); the presence of epithelium in the granuloma was indicated, in which case being classified as epithelialized granuloma.

The immunostaining density was established according to Santos et al. (12) criteria, by determining the intensity of staining of CDla-positive cells in representative fields of all specimens. Specimens showing the largest and smallest number of CDla-positive cells were used as reference and classified as presenting intense (3) and discrete (1) immunostaining, respectively. The other 
specimens were classified as presenting moderate (2) or none $(0)$ immunostaining. The scale of Liapatas et al. (10), modified to a score from 0 to 3 was used to grade the intensity of CD3 and Ki67 immunostaining. The scale corresponds to the percentage of stained cells with each specific antibody compared to the total cellular infiltration; counting was scored from 0 to 3: 0 ) no cells stained; 1) weak staining or few cells stained (11-25\%); 2) moderate staining or some cells stained $(26-75 \%)$; 3 ) intense staining or many cells stained (more than $76 \%$ ).

\section{Results}

\section{- Histological evaluation}

Eighteen scar lesions, 6 periradicular cysts and 46 granulomas (of which 18 were epithelialized), were diagnosed.

- Langerhans cells: CDla

CD1a was seen in $32.8 \%(n=23)$ of the lesions: in all cysts $(n=6)$ and in $72.2 \%$ of epithelialized granulomas $(n=13)$, in $14.2 \%$ of granulomas without epithelium $(n=4)$ and in none of the scar lesions. The immunos- taining densities in the cyst lining were discrete in 2 cases (Figure 1), moderate in 3 and intense in 1; in the epithelialized granulomas a discrete density was seen in 5 lesions, moderate in 6 lesions and intense in 2 . The 4 lesions without epithelium but with CD1a staining showed discrete density (Table 2).

- Infiltrating inflammatory cells: CD3

Periapical lesions had diffuse inflammatory cell infiltration in the inner granulation tissues and perivascular infiltration in the outer fibrous tissues; several inflammatory cells were seen infiltrated within the epithelial components in these lesions. CD3 immunohistochemical staining was found in all lesions, but with different values in relation to histological subtypes (Table 2): in scar lesions the presence of lymphocytes was weak in 10 lesions and moderate in 8; in granulomas (pure and epithelialized) an intense immunostaining was seen in 28 lesions, moderate in 9 and weak in 9 lesions; and in radicular cysts the inflammatory cell density was moderate in all lesions (Figure 1).

Table 2. Immunostaining scores in relation to histological subtype of periapical lesions.

\begin{tabular}{|c|c|c|c|c|c|}
\hline \multirow[b]{2}{*}{ Antibody } & \multirow[b]{2}{*}{ Scores } & \multicolumn{4}{|c|}{ Histological subtypes (number of lesions $=70$ ) } \\
\hline & & $\begin{array}{l}\text { Pure granuloma } \\
\qquad(\mathrm{n}=28)\end{array}$ & $\begin{array}{l}\text { Epithelialized gra- } \\
\text { nuloma }(\mathrm{n}=18)\end{array}$ & $\begin{array}{l}\text { Cysts } \\
(\mathrm{n}=6)\end{array}$ & $\begin{array}{l}\text { Scar tissue } \\
\quad(\mathrm{n}=18)\end{array}$ \\
\hline \multirow{4}{*}{ CD1a } & 0 & 24 & 5 & 0 & 18 \\
\hline & 1 & 4 & 5 & 2 & 0 \\
\hline & 2 & 0 & 6 & 3 & 0 \\
\hline & 3 & 0 & 2 & 1 & 0 \\
\hline \multirow{4}{*}{ CD3 } & 0 & 0 & 0 & 0 & 0 \\
\hline & 1 & 7 & 2 & 0 & 10 \\
\hline & 2 & 4 & 5 & 6 & 8 \\
\hline & 3 & 17 & 11 & 0 & 0 \\
\hline \multirow{4}{*}{ Ki67 } & 0 & - & 0 & 0 & - \\
\hline & 1 & - & 16 & 2 & - \\
\hline & 2 & - & 2 & 4 & - \\
\hline & 3 & - & 0 & 0 & - \\
\hline
\end{tabular}

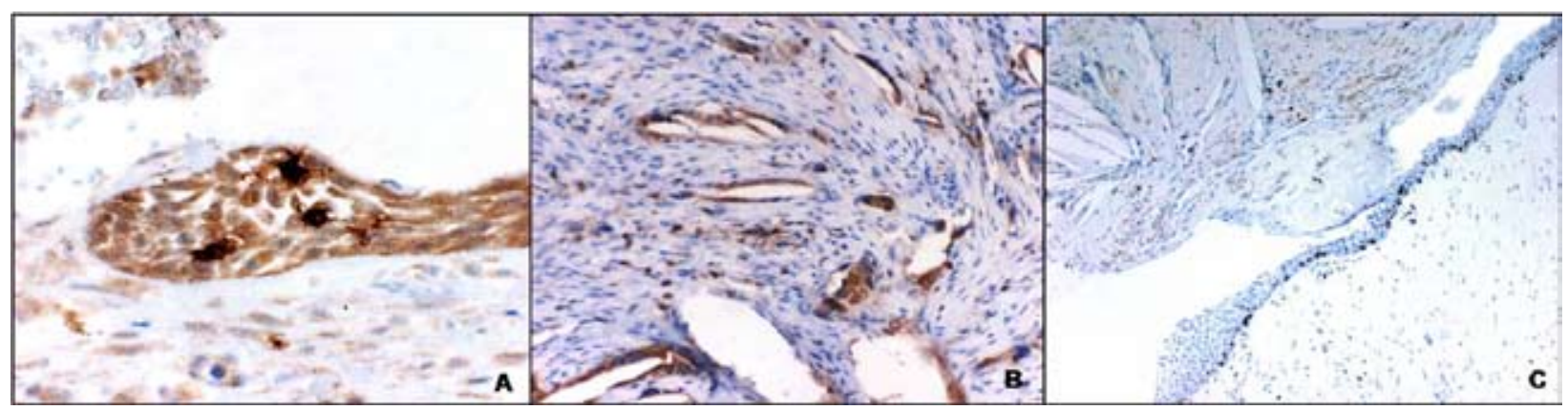

Fig. 1. A) Radicular cyst demonstrating immunoreactivity for CD1a (400x). B) Immunostaining for CD3 in a radicular cyst (200x).C) Moderate staining of Ki67 in a radicular cyst (100x). 
- Epithelial cells proliferation: Ki67

Nuclei positively stained for Ki67 antigen were seen in all epithelialized periapical lesions (Table 2). Staining was weak in 16 epithelialized granulomas and moderate in 2; and moderate in 4 cysts and weak in 2 (Figure 1).

\section{Discussion}

In periapical periodontitis, CD1a immature dendritic cells (DC) may capture and process microbial antigens within inflamed tissue and then migrate to the draining lymph node, where, as mature DC, they activate naive T cells and trigger specific T-cell immune responses. This causes clonal expansion of naive $\mathrm{T}$ cells and their differentiation into effector and memory $\mathrm{T}$ cells. Such $\mathrm{T}$ cells migrate to the site of inflammation where, upon reactivation with local antigen presenting cells, they perform different effector functions. In chronic inflammation, such as periapical periodontitis, a number of DC are retained at the site and undergo local maturation (13).

Suzuki et al. (3) made an immunohistochemical analysis of CDla-labeled Langerhans cells in 83 periapical lesions using antigen markers Ki-67 and topoisomerase II $\alpha$, observing immunostaining for these cells in all periapical lesions, in contrast to Santos et al. (12) who detected Langerhans cells in $45.5 \%$ of the lesions. Similar results were found in the present study, where positivity for CDla was observed in $32.8 \%$ of lesions, which may be due to the presence of scar lesions and non epithelialized granulomas with very little immunostaining. On the other hand, Nilsen et al. (14), found no Langerhans cells in periapical inflammatory lesions using monoclonal antibodies (OKT6-positive cells). Gao et al. (15) found no Langerhans cells in the epithelial rests of Malassez, although some were found in epithelia within periapical granuloma and in most epithelial linings of odontogenic cysts; they concluded that the presence of immune cells in periapical granulomas and cysts suggests that cell-mediated and humoral immunoreactions occur in these lesions and may be associated with the epithelial proliferation within the periapical lesions. Langerhans cells $(\mathrm{CD1}+)$ were identified, mostly in the epithelium $(3,16)$.

Santos et al. (12) found a significant correlation between immunostaining and the lesion type, detecting LCs in $69.2 \%$ of the radicular cysts studied and in $11.1 \%$ of the granulomas; Suzuki et al. (3) observed immunostaining for these cells in $100 \%$ and $95 \%$ of this type of lesion, respectively. In the present study, LCs were seen in $100 \%$ of cysts and in $36.9 \%$ of granulomas. Santos et al. (12) related the decrease in LC number in some cysts to a process of cell apoptosis after antigen presentation to $\mathrm{T}$ cells; in addition, variations in the methods used and in immunohistochemical sensitivity may interfere with the results.

$\mathrm{T}$ lymphocytes play a central role in controlling and maintaining immune reactions and dominate in lesions presenting persistent antigens (17). Suzuki et al. (3) suggested that $\mathrm{CD} 3$ positive cells may be induced by CDlalabeled cells in periapical lesions. Murase et al. (18) made an immunohistochemical demonstration of S-100 protein in Langerhans cells, observing an incidence of positive staining LCs in 22 cases out of 40 radicular cysts; they concluded that these cases were usually accompanied with a high degree of inflammatory infiltration in their lesions; on the contrary, the negative cases also generally lacked inflammatory responses. We observed a higher density of LCs in lesions with an intense and moderate inflammatory infiltrate $(61.1 \%$ of epithelialized granulomas had an intense infiltrate and $100 \%$ of cysts had moderate), as also reported by other authors $(3,12,19)$. Akhlaghi and Dourov (16), in a study based on 142 cysts, concluded that the LC number is not always correlated with an inflammatory condition. Santos et al. (12), believe that the inflammatory intensity is not only related to an increased amount of antigen in the lesion, but also to an exacerbated response of the defence mechanisms of the individual.

Inflammatory stimulation is thought to cause epithelial proliferation (20), Suzuki et al (3), observed a significant direct correlation between the density of CDla-labeled cells and the proliferative potential of the epithelium. In this study nuclei positively stained for Ki67 antigen were seen in all epithelialized lesions, in which a higher density of LCs was also observed.

\section{Conclusions}

Langerhans cells appear to be associated with T lymphocyte infiltration and proliferative potential of the epithelial tissue in periapical lesions. Future studies of these relations in more periapical lesions, will significantly improve our knowledge of these immune cells.

\section{References}

1. Lombardi T, Hauser C, Budtz-Jörgensen E. Langerhans cells: structure, function and role in oral pathological conditions. J Oral Pathol Med. 1993;22:193-202.

2. Katz SI, Tamaki K, Sachs DH. Epidermal Langerhans cells are derived from cells originating in bone marrow. Nature. 1979;282:324-6.

3. Suzuki T, Kumamoto H, Ooya K, Motegi K. Immunohistochemical analysis of CD1a-labeled Langerhans cells in human dental periapical inflammatory lesions--correlation with inflammatory cells and epithelial cells. Oral Dis. 2001;7:336-43.

4. Shear M, Speight P. Cysts of the oral and maxillofacial regions. 4th ed Oxford: Blackwell Munksgaard; 2007. p.129.

5. Kaneko T, Okiji T, Kan L, Takagi M, Suda H. Ultrastructural analysis of MHC class II molecule-expressing cells in experimentally induced periapical lesions in the rat. J Endod. 2001;27:337-42.

6. Kontiainen S, Ranta H, Lautenschlager I. Cells infiltrating human periapical inflammatory lesions. J Oral Pathol. 1986;15:544-6.

7. Gerdes J, Lemke H, Baisch H, Wacker HH, Schwab U, Stein H. Cell cycle analysis of a cell proliferation-associated human nuclear antigen defined by the monoclonal antibody Ki-67. J Immunol. $1984 ; 133: 1710-5$ 
8. Trowbridge HO. Immunological aspects of chronic inflammation and repair. J Endod. 1990;16:54-61.

9. Marton IJ, Kiss C. Characterization of inflammatory cell infiltrate in dental periapical lesions. Int Endod J. 1993;26:131-6.

10. Liapatas S, Nakou M, Rontogianni D. Inflammatory infiltrate of chronic periradicular lesions: an immunohistochemical study. Int Endod J. 2003;36:464-71.

11. Penarrocha M, Garcia B, Marti E, Balaguer J. Pain and inflammation after periapical surgery in 60 patients. J Oral Maxillofac Surg. 2006;64:429-33.

12. Santos LC, Ramos EA, Gurgel CA, De Santana EJ, Dos Santos JN. Immunohistochemical detection of Langerhans cells in dental granulomas and radicular cysts. J Mol Histol. 2007;38:201-5.

13. Lukić A, Vasilijić S, Majstorović I, Vucević D, Mojsilović S, Gazivoda D, et al. Characterization of antigen-presenting cells in human apical periodontitis lesions by flow cytometry and immunocytochemistry. Int Endod J. 2006;39:626-36.

14. Nilsen R, Johannessen AC, Skaug N, Matre R. In situ characterization of mononuclear cells in human dental periapical inflammatory lesions using monoclonal antibodies. Oral Surg Oral Med Oral Pathol. 1984;58:160-5.

15. Gao Z, Mackenzie IC, Rittman BR, Korszun AK, Williams DM, Cruchley AT. Immunocytochemical examination of immune cells in periapical granulomata and odontogenic cysts. J Oral Pathol. 1988;17:84-90.

16. Akhlaghi E, Dourov N. Langerhans cells in odontogenic cysts. A retrospective study based on 142 cases. Bull Group Int Rech Sci Stomatol Odontol. 1995;38:71-6.

17. Seymour GJ, Boyatzis S, Powell RN. The autologous mixed lymphocyte reaction (AMLR) as a possible indicator of immunoregulation in chronic inflammatory periodontal disease. J Clin Periodontol. 1986;13:639-45.

18. Murase N, Tatemoto Y, Iwai Y, Okada Y, Mori M. Langerhans cells in odontogenic tumours and cysts as detected by S-100 protein immunohistochemistry. Basic Appl Histochem. 1990;34:135-41.

19. Pringle GA, Daley TD, Veinot LA, Wysocki GP. Langerhans' cell histiocytosis in association with periapical granulomas and cysts. Oral Surg Oral Med Oral Pathol. 1992;74:186-92.

20. Yanagisawa S. Pathologic study of periapical lesions 1. Periapical granulomas: clinical, histopathologic and immunohistopathologic studies. J Oral Pathol. 1980;9:288-300. 